\title{
Calculated Phase Diagrams, Iron Tolerance Limit, and Corrosion of Mg-Al Alloys
}

\author{
Ming Liu, Peter J. Uggowitzer, Patrik Schınutz, and Andrej Atrens
}

The factors determining corrosion are reviewed in this paper, with an emphasis on iron tolerance limit and the production of high-purity castings. To understand the iron impurity tolerance limit, magnesium phase diagrams were calculated using the Pandat software package. Calculated phase diagrams can explain the iron tolerance limit and the production of high-purity castings by means of control of melt conditions; this is significant for the production of quality castings from recycled magnesium. Based on the new insight, the influence of the microstructure on corro. sion of magnesium alloys is reviewed.

\section{INTRODUCTION}

Magnesium alloys are used in trans portation applications due to their low density and adequate strength/weight ratio. A limitation to their service use is corrosion ${ }^{1-5}$ and hence there is much effort to understand their corrosion behavior. ${ }^{6.60}$ An important aspect of the corrosion of magnesium alloys is the high sensitivity to the impurity elements $\mathrm{Fe}, \mathrm{Ni}, \mathrm{Cl}$, and $\mathrm{Co}$. The corrosion of commercial alloys is dominated by the iron content above the iron tolerance limit, and high corrosion rates are expected. For iron contents below the tolerance limits, other factors can influence the corrosion behavior, such as chenical composition and microstructure. The calculated magnesium phase diagrams indicate that the iron impurity tolerance linit is caused by the precipitation of a distinct, iron-rich phase.

\section{Corrosion of Magnesium Alloys}

Stress corrosion cracking (SCC) occurs in frequently encountered environments ${ }^{61-70}$ including distilled water, ${ }^{61.66}$ indicating that water itself is the key

\section{ล

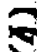

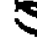

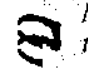
of this paper?

Magnesium alloys are used in Jransportation due to their low density and adequate strength/

0 weight ratio. A limitation to their - service use, however, is corrosion. An important aspect of the corrosion of magnesium alloys is the high sensitivity to the impurity elements

$\mathrm{Fe}, \mathrm{Ni}, \mathrm{Cu}$, and $\mathrm{Co}$. The corrosion rate is low up to a tolerance limit and substantially higher above

$\mathbb{8}$ the tolerance limit. The factors determining corrosion are reviewed,

with an emphasis on the iron

tolerance limit and the production of high-purity castings.

$\infty$ ...describe this work to a materials science and engineering

7 professional with no experience in your technical specialty?

0 The iron tolerance limit for magnesium is explained by using the calculated phase diagram. Above

- the tolerance limit, a separate iron-rich phase forms as a

5 magnesium alloy costing solidifies. This phase is an efficient cathode

and accelerates the corrosion of the

alloy by micro-galvanic coupling to accelerate the corrosion of the

\& magnesium matrix. The phase diagram predicts that the iron tolerance limit is $180 \mathrm{ppm}$ in good

$\theta$

- ...describe this work to a

$\&$ layperson?

Corrosion of magnesium alloys

$-$ Cormits their use in applications such as cars, where the magnesium

$<$. alloys could lead to lighter, morefiwel-efficient, more-environmentfriendly cars. A practical issue for 4 magnesium alloys is that a small content of iron (170 ppm) leads

to high corrosion rates. This work explains that above 180 ppm there is a change of the magnesium alloy that causes the high corrosion rates and how good low-iron castings can be made from poor high-iron feedstock. environmental factor causing SCC in aqueous solutions. The key points of the corrosion mechanism for magnesium alloys ${ }^{1-3}$ are as follows. A partially protective oxide/hydroxide film covers the surface and corrosion occurs at the breaks in this film. The cathodic reaction is hydrogen production. The surface film on magnesium is not particularly protective; the corrosion rate is typically more than $1 \mathrm{~mm} / \mathrm{y}$ in common environments like $3 \% \mathrm{NaCl}$ solution. No alloying element has been discovered that produces a solid-solution magnesium alloy with a corrosion rate less than that of pure magnesium in $3 \% \mathrm{NaCl}$ solution. Consequently, it is useful to include pure magnesium as a standard in any comparative study of corrosion performance of magnesium alloys; $;^{2.21 .35}$ commercial purity magnesium can have a corrosion rate more than 50 times that of pure magnesium..$^{2,17}$

Corrosion of common magnesium alloys typically involves micro-galvanic acceleration ${ }^{2,17,21.34 \cdot 36}$ of the corrosion of the $\alpha-\mathrm{Mg}$ matrix by the second phase(s). The corrosion rate of a twophase magnesium alloy can, however, be lower than that of pure magnesium if the second phase is finely divided, essentially continuous, and the second phase itself has a lower corrosion rate than that of pure magnesium. Then, the second phase can act as a corrosion barrier. The corrosion form of magnesium is typically designated as localized corrosion ${ }^{1,2.36,38}$ to distinguish it from the auto-catalytic pitting in stain less steels.

Corrosion of magnesium has a number of seemingly strange phenomena. The best known is the negative difference effect. ${ }^{1-3.32 .33}$ This effect means that the amount of hydrogen liberated 


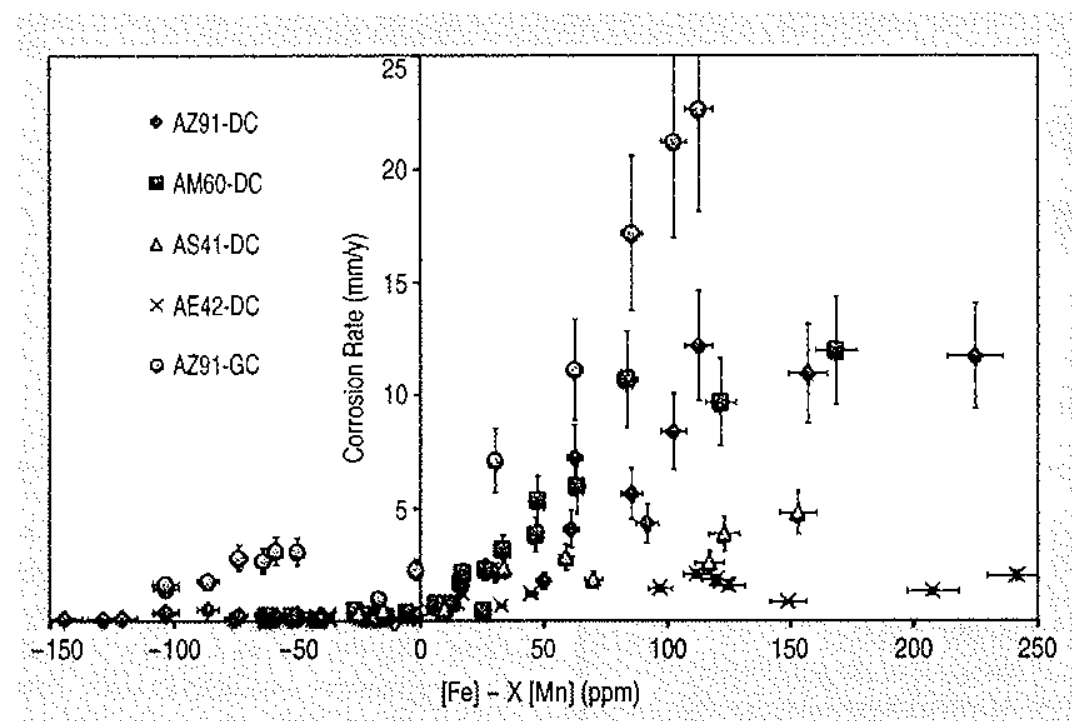

Figure 1. For the magnesium alloys AZ91, AM60, AS41, and AE42, the salt spray corrosion rate $(\mathrm{mm} / \mathrm{y})$ as a function of the alloy iron content $([\mathrm{Fe}])$ above the tolerance limit $(\mathrm{X}[\mathrm{Mn}])$ at the alloy Mn content ([Mn])

increases with increasing applied anodic current (which decreases the cathodic reaction rate and the amount of associated "cathodic" hydrogen) and the amount of magnesium dissolved is greater than expected from application of the Faraday Law. Another wellknown effect is that electrochemical measurements of the corrosion rate, based on the corrosion current at the free corrosion potential, do not agrec with direct measurements using weight loss or evaluated from the evolved hydrogen. ${ }^{2,30.36,46,71}$

\section{Influence of Iron on Magnesium Corrosion}

The corrosion rate is low up to a tolerance limit; the corrosion rate is substantially higher above the tolerance limit (the factor may be 100x). Typical values of tolerance limits are given in Table I. There are two hypotheses ${ }^{1.2}$ for the tolerance limits of $\mathrm{Fe}, \mathrm{Ni}, \mathrm{Cu}$, and Co: phase precipitation and surface deposition. Both the phase precipitation and surface deposition hypotheses assume that effective hydrogen cathodes are produced above the tolerance limit, and both assume that these cathodies have a composition rich in the impurity element. The essential difference is that the phase precipitation hypothesis relates to the precipitation of a new phase inside the magnesium alloy whereas the surface deposition hypothesis re- lates to the deposition of cathodes on the magnesium alloy surface. To date there has been no successful resolution regarding which hypothesis is correct.

Some useful insights are gained regarding the mechanism of the iron tolerance limit for the die-cast (DC) and gravity-cast (GC) magnesium alloys AZ91-DC and AZ91-GC, ${ }^{6}$ AM60DC, ${ }^{12}$ AS41-DC, ${ }^{10}$ and AE42 DC. ${ }^{13}$ Figure 1 presents the salt spray corrosion rate (measured over 10 days) as a function of the iron content above the tolerance limit evaluated as "[Fe] $-\mathrm{X} *[\mathrm{Mn}]$ ", where $[\mathrm{Fe}]$ is the iron con" tent of the alloy, $[\mathrm{Mn}]$ is the manganese content of the alloy, and $\mathrm{X} *[\mathrm{Mn}]$ is the alloy-dependent iron tolerance limit which depends on the manganese concentration and on the alloy (i.e., the weighting factor $X$ is alloy-dependent, particularly dependent on alloy aluminum content, as shown in Table I). Figure 1 shows that, first, the corrosions rate is low below the tolerance limit and high above the tolerance limit, and second, above the tolerance limit, the corrosion rate increases rapidly in a non-linear fashion, which is dependent on alloy and casting method.

This behavior is consistent with a second phase above the tolerance limit, with the phase in each case having somewhat different ability to act as a cathode and liberatc hydrogen. It is hard to reconcile Figure I with the second explanation for the tolerance limit, namely that the probability of producing surface iron cathodes increases with iron content.

\section{High-Purity Castings}

That the tolerance level is related to the precipitation of a separatc phase is also supported by the controlled casting experiments of J.E. Hillis and coworkers using AZ91, ${ }^{6}$ AM60, ${ }^{12}$ and AS41, ${ }^{10}$ These experiments demon strated that high-purity alloys could be

\begin{tabular}{|c|c|c|c|c|c|}
\hline \multicolumn{6}{|c|}{ Table 1. Tolerance Limits for Magnesium Alloys' } \\
\hline Alloy & Condition & $\mathrm{Fe}$ & $\underset{(p p m)}{\mathrm{Ni}}$ & $\underset{(\mathrm{ppm})}{\mathrm{Cu}}$ & Reference \\
\hline Pure $\mathrm{Mg}$ & & $\{70 \mathrm{ppm}$ & 5 & 1,000 & 4 \\
\hline Pure Mg & & $170 \mathrm{ppm}$ & 5 & 1,300 & 5 \\
\hline AZ91 & & 20 ppm & 12 & 900 & 5 \\
\hline AZ91 & & $0.032 * \mathrm{Mn}$ & 50 & 400 & 4,6 \\
\hline$A Z 91$ & $\operatorname{HPDC}(\mathrm{F})$ & $0.032 * \mathrm{Mn}$ & 50 & 400 & 7,8 \\
\hline$A Z 91$ & $\mathrm{LPDC}(\mathrm{F})$ & $0.032 * \mathrm{Mn}$ & 10 & 400 & 7 \\
\hline AZ91 & LPDC (T4) & $0.035 \times \mathrm{Mn}$ & 10 & 100 & 6,7 \\
\hline AZ91 & $\mathrm{LPDC}(\mathrm{T} 6)$ & $0.046 * \mathrm{Mn}$ & 10 & 400 & 7 \\
\hline AZ91B & & & $<100$ & $<2,500$ & 9 \\
\hline AZ91 & Die cast & $0.032 * \mathrm{Mn}$ & 50 & 400 & 10 \\
\hline AZs1 & Die cast & 50 ppm & 50 & 700 & 9 \\
\hline$A Z 91$ & Die cast & $0.032 * \mathrm{Mn}$ & 50 & 700 & 6 \\
\hline$A Z 91$ & Gravity cast & $0.032 * \mathrm{Mn}$ & 10 & 400 & 6 \\
\hline AM60 & Die cast & $0.021 * \mathrm{Mn}$ & 30 & 10 & $10-12$ \\
\hline $\mathrm{AE} 42$ & Die cast & $0.020 * \mathrm{Mn}$ & 40 & 400 & 13 \\
\hline AS41 & Die cast & $0.010 * \mathrm{Mn}$ & 40 & 200 & $10-13$ \\
\hline
\end{tabular}

"HPDC = high-pressure die cast; LPDC $=$ low-pressure die cast 
produced from low-purity alloys by control of the casting temperature. For the AZ91 experiments, they used $\sim 40$ $\mathrm{kg}$ heats of high-purity AZ9l-base alloys containing $\sim 9 \% \mathrm{Al}, 0.5 \% \mathrm{Zn}, \sim 390$ ppm $\mathrm{Fe},<10 \mathrm{ppm} \mathrm{Ni}$ and $<100 \mathrm{ppm}$ $\mathrm{Cu}$. The alloy was equilibrated with $0.2 \% \mathrm{Mn}$ (trial 1), $0.4 \% \mathrm{Mn}$ (trial 2), or $0.8 \% \mathrm{Mn}$ (trial 3 ) at $750^{\circ} \mathrm{C}$; die castings were made at $750^{\circ} \mathrm{C}$ and after equilibration for $10-15 \mathrm{~min}$. at three lower nominal temperatures: $725^{\circ} \mathrm{C}, 690^{\circ} \mathrm{C}$, and $650^{\circ} \mathrm{C}$ (in each case they measured the actual temperature of the melt at the time of casting, and these actual temperatures were somewhat different than the nominal temperatures). Chemical analysis of the die castings revealed the chemical composition of the melt just before casting. Chemical analysis of the dic castings of trial 1 indicated a decrease in only the iron content as the melt temperature was decreased from $750^{\circ} \mathrm{C}$ to $690^{\circ} \mathrm{C}$, consistent with the precipitation from the melt of an ironrich phase containing no manganese; each of these die castings had an iron content above the mangancse-dependent tolerance limit and had a high corrosion rate in the salt spray test. The trial 1 die-casting at $650^{\circ} \mathrm{C}$ had a lower iron composition and a lower manga nese composition, indicating the precipitation of both these elements from the melt between $690^{\circ} \mathrm{C}$ and $650^{\circ} \mathrm{C}$, which could be by the precipitation of a

Table II. Values of the Measured Critical Melt Temperature, $T_{\mu}$, Measured for AZ91, AM $60^{12}$ and $A S 41^{10 *}$

\begin{tabular}{|c|c|c|c|c|}
\hline Alloy & $\begin{array}{c}\text { Al } \\
\text { (wt.\%) }\end{array}$ & $\begin{array}{c}{[\mathrm{Mn}]_{750 \mathrm{C}}} \\
(\mathrm{wt} . \%)\end{array}$ & $\begin{array}{c}T_{4} \\
\left({ }^{\circ} \mathrm{C}\right)\end{array}$ & $\begin{array}{l}{ }^{\top} \mathrm{C} \\
\left({ }^{\circ} \mathrm{C}\right)\end{array}$ \\
\hline AZ91 & 9 & 0.2 & 654 & 640 \\
\hline AZ91 & 9 & 0.4 & 694 & 690 \\
\hline AZ91 & 9 & 0.8 & $>750$ & 760 \\
\hline AM60 & 6 & 0.2 & 640 & 620 \\
\hline AM60 & 6 & 0.4 & 650 & 670 \\
\hline AM60 & 6 & 0.8 & 720 & 720 \\
\hline AS41 & 4 & 0.2 & $<660$ & 620 \\
\hline AS41 & 4 & 0.4 & 658 & 630 \\
\hline AS41 & 4 & 0.8 & - & 685 \\
\hline
\end{tabular}

- $T_{u}$ is the temperature at which low corrosion rates were maasured and above which there was precipitation of both $\mathrm{Fe}$ and $\mathrm{Mn}$ from the mell. [Mn] $]_{\text {, }}$ is the Mn concentration in the starling melt at $750^{\circ} \mathrm{C}$; the die castings typically contained a lower Mn concentration. $T$ is the temparature at which the calculated $\mathrm{Mg}-\mathrm{Al}-\mathrm{Mn}$ - $\mathrm{Fe}$ phase diagrams predict that solidification of a casting would lead to no bcc phase in the casting.

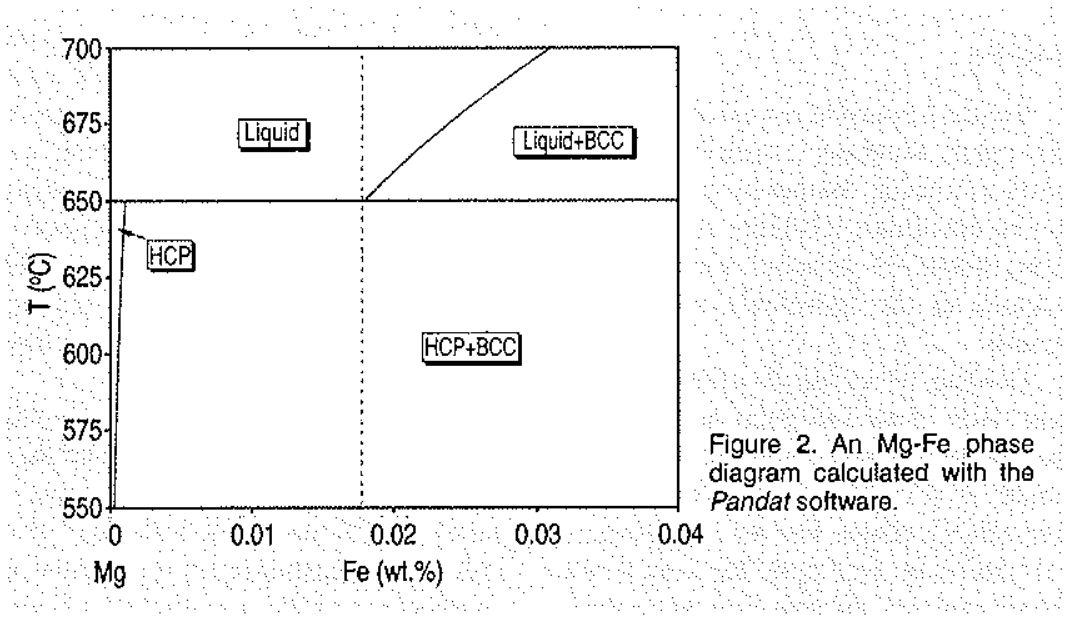

single $\mathrm{Fe}_{3} \mathrm{Mn}_{\mathrm{b}}$ compound or by the precipitation of two compounds, one ironrich, the other manganese rich. The trial $1650^{\circ} \mathrm{C}$ casting had an iron content below the tolerance limit and a low corrosion rate in the salt spray test. The other trials with AZ91, and the subsc . quent trials with AM60 ${ }^{12}$ and AS41, ${ }^{10}$ revealed similar trends. Table Il presents the values of the measured critical melt temperature, $T_{\mathrm{A}}$, at which castings were produced with measured low corrosion rates and above which there was precipitation of both iron and manganese from the melt.

\section{Research Goals}

The present study has the following aims: use calculated magnesium phase diagrams to understand the metallurgy of the influence of iron impurities on the corrosion of magnesium alloys, and use calculated magnesium phase diagrams to explain the production of high-purity magnesium castings by controlling melt conditions so that the castings have excellent corrosion properties.

\section{Calculated phase DIAGRAMS}

To understand the iron impurity tolerance limit, magnesium phase diagrams were calculated using the Pandat software package (database $\operatorname{Pan} \mathrm{Mg} 7$; it comprises 18 components with the following composition limits: $0-10$ wt.\% for $\mathrm{Al}, \mathrm{Ca}, \mathrm{Li}, \mathrm{Mn}, \mathrm{Si}$, and $\mathrm{Zn} ; \mathrm{O}_{-1}$ wt. \% for $\mathrm{Ag}, \mathrm{Ce}, \mathrm{Gd}, \mathrm{Nd}, \mathrm{Sc}, \mathrm{Sn}, \mathrm{Sr}, \mathrm{Y}$, $\mathrm{Zr}, \mathrm{Fe}$, and $\mathrm{Cu} ; 346$ different phases are considered). ${ }^{72}$ The phase diagrams so calculated use the thermodynamic data in the latest Pandat magnesium databasc. The thermodynamic data has not becn optimized at all for these calcula tions. Thus, it is likely that particular numerical values may be somewhat in error, but the trends can be assumed to be valid. Furthermore, the database is not complete; it includes data for iron and copper; but not nickel or cobalt For the present case, phase diagrams have been calculated to understand the tolerance limit for iron. 


\section{$\mathrm{Mg}-\mathrm{Fe}$}

Figure 2 presents the calculated $\mathrm{Mg}$ $\mathrm{Fc}$ phase diagram: a eutectic system with a cutectic temperature of $650^{\circ} \mathrm{C}$ and a maximum solubility of $\approx 10 \mathrm{ppm}$ iron. Table III presents details of the phases in the calculated phase diagrams.

Cooling of an $\mathrm{Mg}-\mathrm{Fe}$ alloy containing more than $180 \mathrm{ppm}$ is predicted to cause the solidification, from the melt, of a separate body-centered cubic (BCC) phase. For an iron content of less than $180 \mathrm{ppm}$ the calculated phase diagram predicts that on cooling the liquid magnesium alloy undergoes cutectic solidification at $650^{\circ} \mathrm{C}$ to form $\alpha-\mathrm{Mg}$ containing about $10 \mathrm{ppm}$ iron in solid solution plus the $\mathrm{BCC}$ phase. However, the two-phase region (liquid $\mathrm{Mg}+\alpha-\mathrm{Mg}$ ) is extremely narrow, so that it would be expected that the preeutectic and eutectic reaction would be suppressed during normal (non-equilibrium) cooling of a magnesium ingot or casting. Thus a magnesium alloy con- taining less than $180 \mathrm{ppm}$ iron would solidify to a single $\alpha \cdot \mathrm{Mg}$ phase with iron in solid solution in the magnesium lattice. If this is indeed correct, the implication is that there is single-phase magnesium up to a critical iron concentration of $180 \mathrm{ppm}$ and that there would be a separate $\mathrm{BCC}$ phase (rich in iron) for a magnesium casting with an iron content grcater than $180 \mathrm{ppm}$.

This value of $180 \mathrm{ppm}$ iron should be compared with the iron tolerance level in pure as-cast magnesium reported to be $170 \mathrm{ppm}^{1,46}$ or $150 \mathrm{ppm}^{7}$ The calculated phase diagram thus offers an cxplanation of the iron tolcrance limit: It corresponds to the minimum content of iron in a cast magnesium alloy for which a $\mathrm{BCC}$ phase solidifies from the melt beforc final solidification.

The phase diagram allows an estimation of how much second phase forms for a given alloy in equilibrium. For a magnesium alloy containing $280 \mathrm{ppm}$ iron, the fraction of the primary $\mathrm{BCC}$ phase, $f_{B C c / c a s t i n g}$, can be calculated using the lever rule as follows:

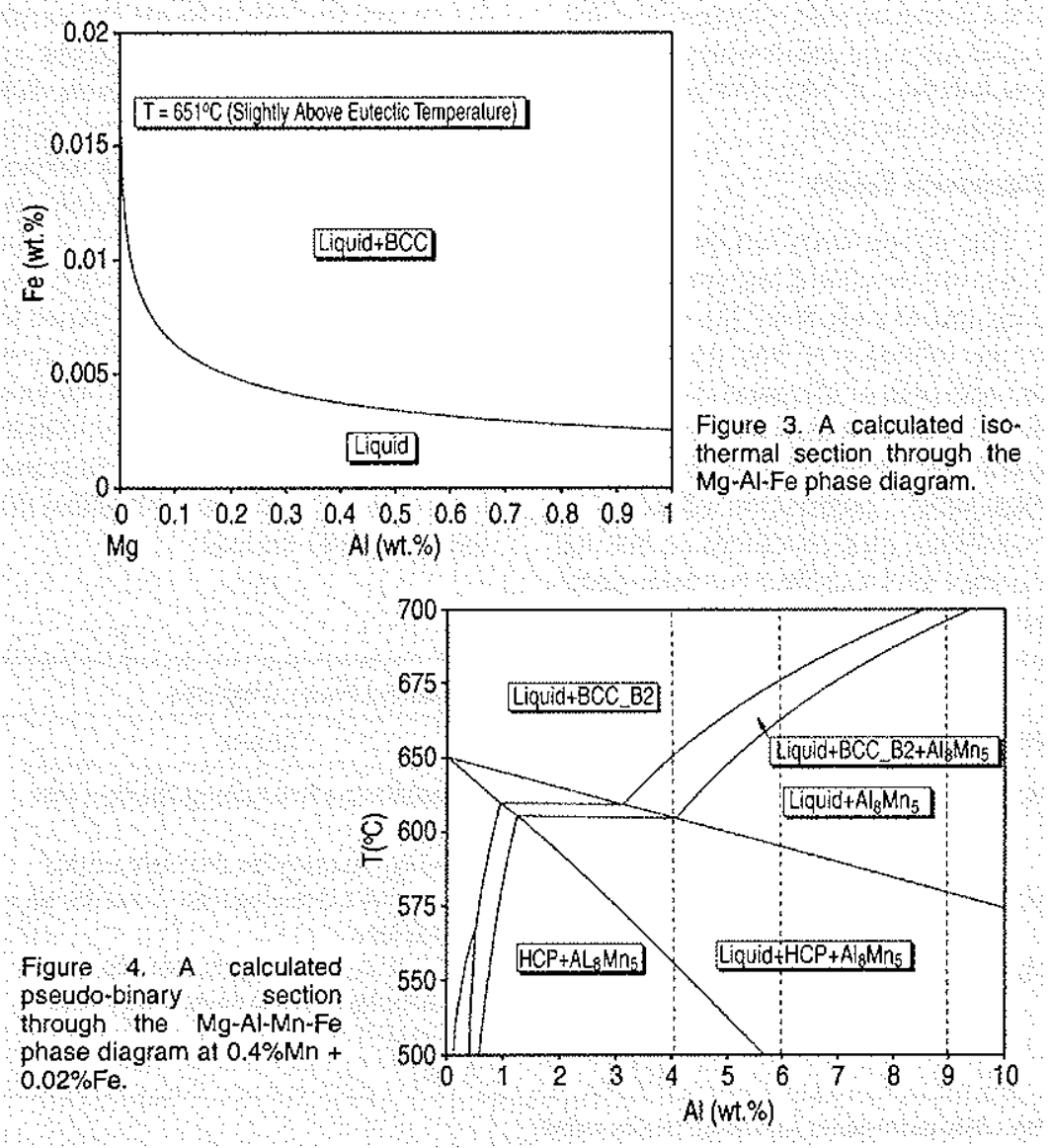

Table IV. Summary of the Influence of Composition and Microstructure on the Corrosion of $\mathrm{AZg1}^{7^{\circ}}$

\begin{tabular}{|c|c|c|c|c|c|c|}
\hline \multirow[b]{2}{*}{ Alloy } & \multirow[b]{2}{*}{$\operatorname{Mn}(\%)$} & \multirow[b]{2}{*}{ Fe/Mn } & \multicolumn{4}{|c|}{$\begin{array}{l}\text { Salt Spray Corrosion } \\
\text { Rate }(\mathrm{mm} / \mathrm{y})\end{array}$} \\
\hline & & & $F$ & T4 & T6 & T5 \\
\hline & 0.18 & 0.087 & 18 & 15 & 15 & $\ldots$ \\
\hline 2911 & 0.23 & 0.008 & 0.64 & 4 & 0.15 & 0.12 \\
\hline
\end{tabular}

${ }^{\circ} \mathrm{F}$ is as-cast, $\mathrm{T} 4$ is solution treated $\left(16 \mathrm{~h}\right.$ at $410^{\circ} \mathrm{C}$ and quenched), T6 is solution ireated and aged ( $16 \mathrm{~h}$ at $410^{\circ} \mathrm{C}$ and quenched, $4 \mathrm{~h}$ at $215^{\circ} \mathrm{C}$ ), and $\mathrm{T5}$ is aged ( $\mathrm{h}$ al $215^{\circ} \mathrm{C}$.

$$
\begin{gathered}
\mathrm{f}_{\text {BCC/casting }}=(0.028-0.018) \\
/(100-0.018)=0.01 \%
\end{gathered}
$$

If this $\mathrm{BCC}$ phase is responsible for increasing the corrosion rate by a factor of 100 above that of high-purity magnesium, then the $\mathrm{BCC}$ phase needs to evolve hydrogen $10^{6}$ times faster than on $\alpha-\mathrm{Mg}$.

\section{Mg-Al-Fe}

Figure 3 presents an isothernal section through the $\mathrm{Mg}-\mathrm{Al}-\mathrm{Fe}$ phase diagram, calculated for $651^{\circ} \mathrm{C}$, slightly above the eutectic temperature. This isothermal section indicates that the eutectic point is shifted to lower iron contents and thus the iron tolerance limit decreases rapidly with increasing aluminum content. The trend of decreasing iron tolerance limit with aluminum alloying has been previously documented (Table I). Figure 3 provides a particular numerical prediction and indicates that there is a significant decrease with a few tens of percent of aluminum.

\section{$\mathrm{Mg}-\mathrm{Al}-\mathrm{Mn}-\mathrm{Fe}$}

Figure 4 presents a pseudo-binary section calculated through the Mg-AI$\mathrm{Mn}-\mathrm{Fe}$ phase diagram at $0.4 \% \mathrm{Mn}$ and $0.02 \% \mathrm{Fe}$; this section was calculated to try to understand the controlled casting experiments (described in the prior section on high-purity castings) carried out by Hillis and co-workers with AZ91, AM60, ${ }^{13}$ and AS4. ${ }^{10}$ Figure 4 indicates that cooling of an alloy containing $6 \%$ aluminum causes initially the precipitation of an iron-rich BCC phase labeled BCC_B2. Between $\sim 675$ and $\sim 670^{\circ} \mathrm{C}$ there is a three-phase region of liquid + $\mathrm{BCC} \ldots \mathrm{B} 2+\mathrm{Al}_{8} \mathrm{Mn}_{5}$. Following the experiments of Hillis and co-workers ${ }^{6.10 .13}$ it is assumed that the BCC_B2 phase 
settles out as the cast is slowly cooled and that the alloy as-cast at $670^{\circ} \mathrm{C}$ contains no BCC_.B2 phase but only magnesium liquid $+\mathrm{Al}_{8} \mathrm{Mn}_{5}$. If it is assumed that the phase $\mathrm{Al}_{8} \mathrm{Mn}_{5}$ is passive (i.e., it is no more effective as a cathode than pure magnesium) then a $6 \%$ aluminum alloy cast at $670^{\circ} \mathrm{C}$ has an iron content below the iron tolerance limit and would be expected to show a low corrosion rate.

Thus, Figure 4 predicts the critical temperature at which the alloy is cast to produce a casting with a low corrosion rate to be $670^{\circ} \mathrm{C}$; this calculated critical temperature, $T_{C}$, is included in Table II. Similarly, Figure 4 predicts critical temperatures of $690^{\circ} \mathrm{C}$ for $9 \%$ aluminum (corresponding to AZ91) and $620^{\circ} \mathrm{C}$ for $4 \%$ aluminum (corresponding to AS41).

Similarly, the pseudo-binary section was calculated through the $\mathrm{Mg}$ Al-Mn-Fe phase diagram at $0.2 \% \mathrm{Mn}$ $+0.02 \% \mathrm{Fe}$ and $0.8 \% \mathrm{Mn}+0.02 \% \mathrm{Fe}$ to allow comparison with the experiments of Hillis and co-workers starting with $0.2 \% \mathrm{Mn}$ and $0.8 \% \mathrm{Mn}$, respectively. The critical temperatures have been included in Table II, which illustrates a good agreement between the measured critical temperature, $T_{M}$, and the calcu lated critical temperature, $T_{c}$, estimated from the calculated phase diagrams. This indicates the phase diagrams are a useful tool for predicting tolerance limits as well as processing parameters.

\section{INFLUENCE OF MICROSTRUCTURE}

Table IV provides a summary of the influence of microstructure on the salt spray corrosion performance of AZ91.? AZ9lC has an iron content greater than the tolerance limit so that the corrosion rate is high and the iron content dominates the behavior; the iron content overwhelms the influence of the microstructure. AZ91E is high purity, the iron content is below the tolerance limit, and there is a clear influence of the microstructure.

The influence of the microstructure has been elucidated in a number of studies, ${ }^{17}$ and is well illustrated by the recent study of M.C. Zhao et al. ${ }^{35}$ Table $\mathrm{V}$ summarizes the corrosion rate measured for $96 \mathrm{~h}$ immersion in $1 \mathrm{M}$ $\mathrm{NaCl}$ solution for high-purity magnesium and high-purity AZ91 in various metallurgical conditions. For as-cast AZ91, the $\beta$ phase is distributed along the grain boundaries and there is an associated fine lamellar arrangement of $\alpha$ $+\beta$ so that there is essentially a continuous network. This arrangement of the $\beta$ phase provides a combination of corrosion barricr effect and micro-galvanic corrosion acceleration. Thus the corrosion rate is significantly greater than that of high purity magnesium. In the HA3805 and HA3810 conditions, there are large isolated $\beta$ phase particles so there is significant microgalvanic corrosion acceleration. In the solution-treated condition (SS), all $\beta$ is dissolved so that there is a solid solution of $\sim 9 \%$ aluminum in the $\alpha-\mathrm{Mg}$ matrix. There is no second phase, so the corrosion reflects that of a homogeneous $\mathrm{Mg}-\mathrm{Al}$ alloy. The aging at $200^{\circ} \mathrm{C}$ for the SA205 condition produced fine $\beta$ precipitates in the $\alpha$ matrix; a more protective surface film is attributed as the cause for the eorrosion rate in the SA205 condition to be lower than that of the SS condition.

Table VI illustrates the corrosion rate for AZ80 in different processing conditions, as-cast and extruded. ${ }^{29}$ With increasing extrusion temperature more $\beta$ phase dissolves, leading to a non-continuous $\beta$ network and thus increased corrosion rate.

Tables V and VI show the same trend in corrosion rate with heat treatment; the corrosion rates produced by solution immersion are considerably higher than those produced by salt spray testing. It is also worth noting

Table V. The Corrosion Rate $(\mathrm{mm} / \mathrm{y})$ Measured for $96 \mathrm{~h} / \mathrm{mmersion}$ in $1 \mathrm{M} \mathrm{NaCl}$ Solution for High-Purity Magnesium and High-Purity AZ91*

\begin{tabular}{llllll}
\hline As-cast & $\frac{\text { HA3805 }}{16}$ & $\frac{\text { HA3810 }}{43}$ & $\frac{\text { SS }}{24}$ & $\frac{\text { SA205 }}{6}$ & $\frac{\text { High-Purity Mg }}{1}$ \\
\hline
\end{tabular}

"The following conditions were used: as-cast, $\mathrm{HA} 3805$ (homogenization anneal for $5 \mathrm{~h}$ at $380^{\circ} \mathrm{C}$ plus air cooll, $\mathrm{HA} 3810$ (homogenization anneal tor $10 \mathrm{~h}$ at $380^{\circ} \mathrm{C}$ plus air cool), SS (100 h at $410^{\circ} \mathrm{C}$ plus water quench), and SA205 (SS plus age $5 \mathrm{~h}$ at $\left.200^{\circ} \mathrm{C}\right)$.
Table VI.The Corrosion Rate $(\mathrm{mm} / \mathrm{y})$

Measured for Immersion in Short Term

Tests $(\sim 4 \mathrm{~h})$ in $3.5 \% \mathrm{NaCl}$ Solution for

As-cast AZ80 and After Extrusion ${ }^{29}$

\begin{tabular}{llll}
\hline As-cast & $\frac{250^{\circ} \mathrm{C}}{7}$ & $\frac{300^{\circ} \mathrm{C}}{11}$ & $\frac{350^{\circ} \mathrm{C}}{10}$ \\
\hline 0.5 & $\frac{10}{7}$ &
\end{tabular}

that the corrosion rate increased during the immersion tests of Zhao et al. ${ }^{35}$ as the corrosion spread across the specimens, indicating that shorter-term tests would measure lower corrosion rates, although the same trends might expect to be measured.

\section{RECYCLING AND SECONDARY ALLOYS}

The calculated phase diagrams can explain the production of high-purity castings by means of control of melt conditions; this has significance for the production of quality castings from recycled magnesium. As shown by the work of Hillis and co-workers ${ }^{9-1.3}$ using commercial HPDC, high-purity castings can be produced by control of the melt, particularly the melt temperature. The alternative approach is to develop tailored alloys that are less sensitive to the impurity elements (c.g., as by the research of C. Scharf et al) ${ }^{30}$

\section{ACKNOWLEDGEMENTS}

This work was supported by the ARC Center of Excellence, Design of Light Alloys. M. Liu and A. Atrens would like to thank EMPA for their support that allowed the authors to spend considerable periods in the EMPA laboratory. EMPA is the Swiss Federal Laborato. ries for Materials Science and Technol ogy. M. Liu and A. Atrens would also like to thank Ecole Nationale Supérieure de Chimie de Paris (ENSCP) and the Université Pierre et Marie Curie for support that allowed them to spend considerable periods in the Laboraroire de Physico-Chimie des Surfaces, CNRS-ENSCP (UMR 7045), Ecole Nationale Supérieure de Chimie de Paris (ENSCP), 11 rue Pierre et Marie Curie, 75005 Paris, France.

\section{References}

1. G. Song and A. Atrens, Advanced Engineering Materials, I (1999), p. 11.

2. G.L. Song and A. Atrens, Advanced Engineering Materials, 5 (2003), p. 837.

3. G. Song and A. Atrens, Advanced Engineering 
Materials, 9 (2007), pp. 177-183.

4. G.L. Makar and J. Kruger, international Materials fieviews, $38(1993)$, p. 138.

5. J.D. Hanawalt, C.E. Nelson, and J.A. Peloubet, Trans. AME, 147 (1942) 0.273

6. K.N. Reichek, K.L. Clark, and J.E. Hillis, SAE Technical Paper 850417 (Warrendale, PA: SAE, 1985) 7. A. Froats et al., Melal Handbook, 9 th ed., Vol .13 (Materials Park, OH: ASM International, 1987), pp. 740-754

8. O. Lunder, T.K. Aune, and K. Nisancioglu, Corrosion, 43 (1987), p. 291.

9. J.E. Hillis, SAE Technical Paper 830523 (Warrendale, PA: SAE, 1983)

10. J.E. Hillis and S.O. Shook, SAE Technical Paper 890205 (Warrendale, PA: SAE, 1989).

11. J.E. Hillis and R.W. Murray (Presentation at the SDCE 14th International Die Casting Congress and Exposition, Toronto, Canada, 1987), Paper No. G-T87. 003.

12. J.E. Hillis and K.N. Reichek, SAE Technical Paper 860288 (Warrendale, PA: $S A E, 1986$ )

13. W.E. Mercer II and J.E. Hillis, SAE Technical Paper 920073 (Warrendale, PA: SAE, 1992).

14. O. Lunder et al., Corrosion, 45 (1989), p. 741.

15. G. Song, A.L. Bowles, and D.H. StJohn, Materials Science and Engineering A, 366 (2004), p. 74.

16. R. Ambat, N.N. Aung, and Z. Zhou, Corrosion Science, $42(2000)$, p. 1433.

17. G. Song, A. Atrens, and M. Dargusch, Corrosion Science, 41 (1998), p. 249

18. Z. Shi, G. Song, and A. Atrens, Corrosion Science, 47 (2005), 0.2760.

19. A. Pardo et al., Corrosion Science, 50 (2008), p. 823.

20. A. Prado et al., Electrochimica Acla, 53 (2008), p. 7890.

21. M.C. Zhao et al., Advanced Engineering Materials, 10 (2008), p. 104.
22. Z. Shi, G. Song, and A. Atrens, Surface and Coatings Technology, 201 (2006), p. 492.

23. G. Song and D. StJohn, Journal of Light Metals, 2 (2002), p. 1.

24. G. Ballerini et al., Corrosion Science, 47 (2005), pp. 2173-2184.

25. Z. Xuehua et al., Corrosion Science, 48 (2006), $\rho$ 4223.

26. O. Lunder, K. Nisanccioglu, and R.S. Hansen (Presentation at Corrosion of Die Cast Magnesium Aluminum Alloys, Detroit, MI, February/March 1993)

27. A. Srinivasan et al., Intermetallics, 15 (2007), pp 1511-1517.

28. J. Zhang et al., Journal of Alloys and Compounds (2008), doi:10.1016f.jallcom.2008.03.089.

29. M.B. Haroush et al., Corrosion Science, 50 (2008) p. $\{766$.

30. C. Schart el al., Advanced Engineering Materials, 7 (2005), p. 1134

31. C. Hoog, N. Birbills, and Y. Estrin, Advanced Engineering Materials, 10 (2008), p. 579.

32. A. Atrens and W. Dietzel, Advanced Engineering Materials, 9 (2007), pp. 292-297.

33. S. Bender, J. Goellner, and A. Atrens, Advanced Engineering Materials, 10 (2008), p. 583.

34. M.C. Zhao et al., Advanced Engineering Materials, $10(2008)$, p. 93.

35. M.C. Zhao et al., Corrosion Science, 50 (2008), p 1939.

36. Ming-Chun Zhao et al., Corrosion Science, (2008), doi: 10.1016fj.corsci.2008.08.023.

37. G.L. Song et al., Corrosion Science, 39 (1997), pp 855-875.

38. G.L. Song et at., Corrosion Science, 39 (1997), pp. 1981-2004.

39. M. Liu et al., Scripta Malerialia, 58 (2008), pp. $421-424$

40. J.X. Jia et al., Materials and Corrosion, 56 (2005), pp. 468-474.

\section{\% ${ }^{24} \mathrm{Kn}$ TMS KNOWH TEO RESOURCE OEWH}

\section{Yout Matorials sooks and More estoral}

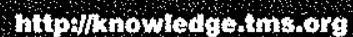

\section{Lectures on the Theory of Phase Transformations: 2 ${ }^{\text {nd }}$ Edition}

Editor: Hubert I. Aaronson

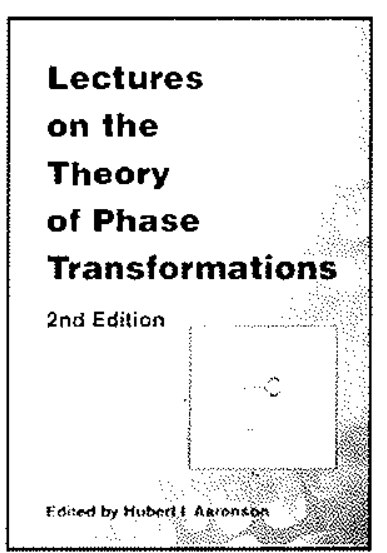

The second edition of this textbook contains updated work by all the first edition's principal authors as well as an additional tutorial overview of the effects of coherency on phase equilibria and phase transformations. The following papers have been updated: Applications of Gibbs Energy-Composition Diagrams; Theory of Capilarity; The Kinetic Equations of Solid-Solid Nucleation Theory and Comparisons with Experimental Observations; and Moving Phase Boundary Problems. Often used in graduate courses on phase zranstormations and on broader topics of which transformations are an important component, this text presents more detailed mathematics than research or review papers or is customary in monographs and textbooks.

Member price \$59; Student price \$35; List price \$84

To order this or related publications, contact TMS:

E-mail publications@tms.org • Phone (724) 776-9000, ext. 256 • Fax (724) 776-3770

41. J.X. Jia, G.L. Song, and A. Atrens, Corrosion Science, 48 (2006), pp. 2133-2153.

42. J.X. Jia, G. Song, and A. Atrens, Advanced Engineering Materials, 9 (2007), pp. 65-74

43. Y. Wan et al., Materials \& Design, 29 (2008), pp. 2034-2037.

44. Y. Wang ef al., Materials Letters, 62 (2008), pp. $2181-2184$.

45. M.B. Kannan and R.K. Singh Raman, Biomaterials 29 (2008), pp. 2306-2314.

46. M. Jönsson, D. Persson, and C. Leygraf, Corrosion Science, 50 (2008), pp. 1406-1413.

47. T. Zhang et al., Electrochimica Acta, 53 (2007), pp. $561-568$.

48. G. Ben-Hamu et al., Materials Science and Engineering: $A_{1} 452-453$ (2007), pp. 210-218

49. G. Song, Corrosion Science, 49 (2007), pp. 16961701.

50. M. Jönsson, D. Persson, and D. Thierry, Corrosion Science, 49 (2007), pp. 1540-1558.

51. J. Chen et al., Electrochimica Acta, 52 (2007), op. 3299-3309.

52. N. Hara et al., Corrosion Science, 49 (2007), pp 166-175.

53. X. Zhou et al, Corrosion Science, 48 (2006), pp. $4223-4233$

54. T. Zhang, Y. Li, and F. Wang, Corrosion Science, 48 (2006), pp. 1249-1264.

55. M.P. Staiger et al., Biomaterials, 27 (2006), pp. 1728-1734.

56. F. Witte et al, Biomaterials, 27 (2006), pp. 10131018.

57. A.-M. Latront et al., Electrochimica Acta, 51 (2005), pp. $489-501$.

58. G. Wu et al., Journal of Applied Electrochemistry 38 (2008), pp. 25$\}-257$.

59. JW. Chang et al. Journal of Applied Electrochemistry, 38 (2008), 0. 207

60.A.D.Südholzetal., Journalof Alloys and Compounds (2008), doi: $\{0.1016 /$ falicom.2008.03.128.

61. N. Winzer et at., Advanced Engineering Materials, 7 (2005), pp. 659-693.

62. N. Winzer et al., Materials Science and Engineering A, 472 (2008), p. 97.

63. N. Winzer et al., Metallurgical and Materials Transactions A, 39 (2008), p. 1157.

64. M. Bobby Kannan et al., Materials science and Engineering $A_{4} 480$ (2008), pp. 529-539.

65. N. Winzer et al., Materials Science and Engineering A, 488 (2008), p. 339 .

66. N. Winzer ef al., Advanced Engineering Materials, $10(2008), 0.453$

67. J. Chen et al., Materials Science and Engineering: $A_{1} 488$ (2008), pp. 428-434.

68. J. Chen et al., Electrochemistry Communications, 10 (2008), pp. 577-581.

69. H. Uchida et al., Environment-induced Cracking of Materials, ed. S. Shipilov et al. (St. Louis, MO: Elsevier, 2008), pp. 323-332.

70. M. Bobby Kannan et al., Scripta Materialia, 57 (2007), pp. 579-581.

71. G. Song, A. Atrens, and D.H. StJohn, Magnesium Technology 2001, ed. J. Hryn (Warrendale, PA: TMS, 2001), p. 255

72. Pandal soltware (CompuTherm, Madison, WI) www.computherm.compandat.him!

Ming Liu and Andrej Atrens are with The University of Queensland, Division of Materials, ARC COE for Design in Light Metals, Brisbane, ald 4072 , Australia; and also Swiss Federal Laboratories for Materiaks Science and Technology, Uberlandstrasse 129, CH +8600 Dubendorf, Switzerland, Patrik Schmutz is with Swiss Federal Laboratories for Materials Science and Technology in Dubendonf, Switzerland; and Peter J. Uggowitzer is with ETH Zurich, Department of Materials, $\mathrm{CH}-8093$ Zurich, Switzeriand. Prof. Atrens can be reached at andrejs,atrens@uq.edu.au. 